\title{
The Impact of Geographic and Business Segment Diversification Upon Investor's Perceptions of Earnings of U.S.-Based Multinational Enterprises
}

by David L. Senteney, School of Accountancy, College of Business, Ohio University, Athens, Can Simga-Mugan, Department of Accounting and Law, School of Management, SUNY Buffalo, Buffalo, NY and Mohammad S. Bazaz, College of Business, Oakland University, Rochester, MI

\section{Abstract}

This study investigates how investors perceive the impact of U.S.-based MNCs geographic and business segment diversification upon their earnings performance. Pooled cross-sectional annual earnings response regressions for the years 1993 through 1997 are used for this investigation. Our results show that geographic segment diversification is valued by investors more than the business segment diversification especially in two cases: 1 ) when the business segmentation is low; and 2) when geographic segmentation is high. These results imply that business segment diversification is only valued when it takes place in international markets where it is relatively more difficult for individual investors to replicate industry diversified portfolio for themselves. Our research illuminates the contextual aspects of investors' perceptions of geographic and business segment diversification for multinational corporations by explicitly controlling for one dimension of corporate diversification while examining the earning-returns impact of the other type of corporate diversification.

\section{Introduction}

The share price effects of geographic and business segment diversification have been extensively researched as globalization trend has become more prominent. Although mixed results exist the preponderance of earlier research indicates that a firm's market value increases in relation to the degree of geographic segment diversification and decreases in relation to the degree of business segment diversification (see Hitt et. al. (1997) for an excellent review, and Arnold,1980; Doupnik and Rolfe, 1989; Prather-Stewart, 1995 among others). One may argue that geographically diversified companies in essence carry their expertise to other locations while business segment diversification suggests a company is moving outside of its core business. Thus, one plausible explanation for observing a positive relationship between the degree of geographic segmentation and market value could be that investors believe they have the opportunity to create business diversification by simply purchasing shares of firms with operations in different domestic industries. Following that reasoning they might also believe that it is more difficult to form an international portfolio of shares and therefore react positively to geographic segments.

Using pooled cross-sectional annual earnings response regressions for the years 1993 through 1997, we find evidence of a differential impact for degree of corporate geographic and business segment diversification upon the association between annual earnings and share price changes of U.S.-based multinational 
corporations (MNCs). The firms are identified using the Statement of Financial Accounting Standard No.14 (SFAS No.14) geographic and business segment disclosures as having significant geographic and business segment operations. Similar numbers (i.e., counts) of geographic and business segments have a differential impact upon the association between magnitudes of MNCs' annual earnings changes and risk-adjusted equity security returns. Consistent with existing literature regarding the share price effects of geographic and business segment diversification, we find positive association between magnitudes of annual risk-adjusted equity security returns and earnings changes in relation to geographic segment diversification. We also find that business segmentation has a positive effect on the association between magnitudes of MNCs' annual earnings changes when companies are already geographically diversified. We contribute to the existing literature in this area by (1) explicitly controlling for the effects of one type of diversification (i.e., geographic or business segment) when examining the impact of the other upon the association between annual earnings and equity security returns of U.S.-based MNCs; and (2) extending the existing literature on the share price effects of geographic and business segment diversification to include the association between annual earnings and share price changes of U.S.-based MNCs (rather than examining the security share price or return affects without considering earnings).

The remainder of the paper is presented in four sections. The first section discusses the underlying intuition and motivation for the study in terms of the existing literature regarding the share price effects of corporate geographic and business segment diversification. The second section describes the research design employed in the study, including the data sources and sample selection. The results are presented and discussed in the context of their contribution to the interpretation of the existing literature in the third section. The conclusion, limitations of this study, and suggestions for future research regarding the share price effects of geographic and business segment diversification are provided in the fourth section.

\section{Background On Geographic and Business Segment Reporting and Their Effects}

Financial analysts have expressed the need for segment or disaggregated financial information throughout the last three decades. SFAS No.14 Financial Reporting for Segments of a Business Enterprise was issued in 1976 as an initial effort to satisfy this need. However, it was apparent by the beginning of the 1990s that the standard should be revised for two main reasons: 1) the standard was not suitable to the integral segmentation of the company; and 2) segmentation was subject to manipulation by the reporting companies (AIMR- Association for Investment Management and Research, 1993). As a result, SFAS No.131 was issued in June 1997, and was effective starting fiscal year 1998 superseding SFAS No.14. The following chart compares the two standards very briefly (SFAS No.14 and SFAS No.131): 


$\begin{array}{lll}\text { Reporting Entity } & \begin{array}{l}\text { SFAS No.14 } \\ \text { public business enterprise }\end{array} & \begin{array}{l}\text { SFAS No.131 } \\ \text { same }\end{array} \\ \text { Segmentation } & \begin{array}{l}\text { geographic area } \\ \text { line of business }\end{array} & \begin{array}{l}\text { specific country operating } \\ \text { segments as used in } \\ \text { internal decision making }\end{array} \\ \text { Disclosure } & \begin{array}{l}\text { geographic: revenues, earnings, } \\ \text { business, revenues, earnings } \\ \text { assets, depreciation and } \\ \text { capital expenditures }\end{array} & \begin{array}{l}\text { segment profit or loss, } \\ \text { and certain revenue and } \\ \text { exspense item }\end{array} \\ & \begin{array}{l}10 \% \text { of consolidated amounts } \\ \text { Reporting Threshold }\end{array} & \begin{array}{l}10 \% \text { of overall revenues, } \\ \text { profits or assets }\end{array}\end{array}$

Although several studies have shown that the disclosures required by SFAS No.14 were helpful in predicting sales, income, and earnings of segments, the same disclosures were criticized by the financial analysts based upon the following issues (Gray and Radebaugh, 1984; Balakrishnan et al., 1990; Mc Connell and Pacter, 1995; and Harris, 1998 among others):

- flexibility provided to the management in definition of segments

- change of segments from one period to the next

- lack of specific data, and

- segments not in accordance with the internal organization of the company.

The disclosures required under SFAS No.131 were aimed at alleviating these problems. However, recent studies that utilize SFAS No.131 disclosures show that some of these problems still prevail. Nichols, et al. (2000) show that although 158 of US Global 1000 companies disclose specific data, their segmentation disclosures still suffer from aggregation problems. Similarly, Herrmann and Thomas (2000) indicate that although companies provide more specific information and there are more country segments under the current disclosures, aggregation problems still continue. Doupnik and Seese (2001) investigate the implementation of SFAS No.131 in Fortune 500 Companies. They find that although the number of companies that have country level disclosures almost doubled from 1997 to 1998 , more than half of the sample companies did not provide any country level information. On the positive side, in 1998 sixty companies started to provide country level information whereas ten companies ceased to do so after SFAS No.131.

Street et al. (2000) compare the 1997 and 1998 annual reports of 160 firms from US Global 1000 companies and conclude that business reporting has improved under the new disclosure standard in terms of number of segments reported and the consistency of information over segments. Almost $50 \%$ of the sample companies - especially the global companies- reported both line-of-business and geographic segment data. The authors conclude

Nevertheless, our results suggest SFAS No.131 has supplied financial statement users with most of the benefits anticipated by the FASB. (p.281) 
However, the AIMR Survey of 2000 shows that participants around the world still include segment or disaggregated information as one of the main issues that publicly traded companies should address if they want the public to have 'quality' financial information thus signifying the importance of disaggregated geographic and/or line-of-business data. In summary, SFAS No.131 responded to some of the demands of the investors but it appears that some improvement is necessary to provide more detailed information. Thomas (2000) finds significant differences in coefficients of geographic segment earnings and concludes that this result is suggestive of the importance of such information for investors. Moreover, he states that valuable information may be lost because of the new segmentation system. Thus, we need additional research regarding the data provided by SFAS No.131 before any conclusive results about the preferences of the investors can be drawn.

\section{Geographic Segment Diversification}

Multinational corporations that operate in various geographic locations and in different industries could present a diversified portfolio of investment projects to individual investors. The amount individual investors are willing to pay multinational corporations in order to obtain such diversification will be reflected via supplemental firm value. Paramount to this issue is the opportunity to utilize the assets better globally and it is believed that such additional returns are capitalized into the value of the firm (Bodnar et al., 1997).

Furthermore, a globally diversified firm has an opportunity to arbitrage governmental restrictions, taxes, low labor cost areas, and low capital raising locations. Having business in multiple geographic locations around the world, a multinational firm has a value advantage by exercising various options such as declaring profit in tax haven countries, operating in a low labor cost locations, moving cash from a restricted area through transfer pricing, and raising capital wherever the cost of borrowing is low. These options suggest that globally diversified firms should be more valuable than domestic firms. Theoretically, the incremental value of the globally diversified firm should be increasing as the available profit maximizing options increase. A recent review states that geographic data helps analysts to appraise the effect of exchange rate risk, political risk and inflation risk (Coller and Pierce, 1999). Global diversification increases coordination, distribution, and management costs. Hitt et al. (1997) argue that trade barriers, logistical costs, cultural diversity, foreign currency risks, and country differences require considerable coordination before the advantages of differences in factor markets and economies of scope can be enjoyed.

In general, previous research has shown that multinational corporations can earn excess equity security returns. Early studies such as Mikhail and Shawky (1979), Brewer (1981), Fatemi (1984), and Michel and Shaked (1986) make various comparisons of domestic firms and geographically diversified multinational corporations, and indicate that multinational corporations outperform their purely domestic counterparts. Errunza and Senbet (1981) find measures of price to book value (i.e., market value of equity to book value of equity) to increase in relation to measures of degree of international involvement indicating that investors attribute some type of excess return or monopoly persistence of earnings to the degree of international involvement. 
Errunza and Senbet (1984) continue this investigation over a different time frame. By holding constant firm's capitalized equity value and using various measures of degree of international involvement, they find a robust and positive association between firms' share value and degree of international involvement. Kim and Lyn (1986) build upon the Errunza and Senbet investigation by controlling for industry concentration, advertising, and research and development expenditures and find increasing excess value for multinational corporations in relation to the degree of international operations. More recently, Morck and Yeung (1991) use measures of capitalized equity value to book value of assets to investigate the impact of number of foreign subsidiaries on firm value. They report that market to book value is positively related to the number of foreign subsidiaries. Tallman and $\mathrm{Li}$ (1996) argue that market returns show both positive and negative relationship to geographic diversification although multinationals seem to have lower levels of risk. Boatsman, et al. (1993) state that they find little evidence that disclosures affect share prices.

\section{Business Segment Dlversification}

Conceptually diversification makes sense and should be profitable, up to a limit. Resource-based (Conner, 1991), dynamic capability (Teece, Pisano, \& Shuen, 1990), and core competency (Prahalad \& Hamel, 1990) theories all advocate the competitive advantage of a diversified firm and state that such a firm should generate superior outputs and greater profitability. Transaction cost theory, on the other hand, suggests that excessive growth will eventually raise governance costs and reduce profits (Jones and Hills, 1988).

Literature on diversification is perhaps one of the largest bodies of work in business strategies. Findings, however, have been contradictory. Using firms' SIC codes, Palepu (1985) finds no significant performance, effects from degree of business diversification. Hoskisson et al. (1993) use a more sophisticated SIC-based measure of business diversification and observe a significant negative association with firm's performance. Several of the studies summarized in Datta et al. (1991) have shown a positive relationship between business diversification and performance measures. The contradictory results may be attributable to the selection of measurement methods. Regardless of the existing results, we can safely argue that as long as higher degrees of diversification create more profit for firms, investors will prefer a diversified firm rather than investing in several firms with one business segment or investing in several firms each located in different countries.

In this study, we consider geographic and business segment diversification simultaneously rather than separately. Such a procedure allows us to examine the effects of one type of diversification while explicitly controlling for the other type of diversification. In addition, our inquiry differs from existing studies in that we introduce earnings as an explanatory variable for equity security returns and investigate how differing degrees of geographic and business segment diversification alters the relation between earnings and equity security returns across MNCs. We a priori believe that differing degrees of geographic business segment diversification may impact the earnings-returns relation for U.S.-based MNCs because size and risk are affected by degree of geographic business segment diversification and variables such are size and risk are known to affect the earnings returns relation. 


\section{Methodology}

We identify firms reporting geographic and business segment disclosures in the notes accompanying audited annual financial statements for the years 1993 through 1997 (inclusive) using the Standard and Poor's Compustat data files. We also require the firms to be calendar year end companies having the following requisite non-missing data items:

- annual number of geographic and business segments reported;

- annual earnings per share (before discontinued operations and extraordinary items), year-end close security price and common-shares-outstanding, and systematic risk measures for the years required; and

- monthly security price, dividend, and stock-dividend and stock-split adjustment data for the time periods required.

We define two qualitative (i.e., dummy variables) variables $\mathrm{G}$ (geographic) and $B$ (business) to partition the sample of firm-year observations into high and low geographic and business segment subsets. Both variables take values of zero for low levels of diversification, and one for high levels of segment diversification. Table 1 shows the distribution of firms across high and low geographic and business segment classifications for the five-year pooled sample. In total, we start with 36,062 firm-year observations of the firms reporting geographic and business segment information, with about $40 \%$ being classified as low geographic diversification and low business segment diversification, about $9 \%$ being classsified as high geographic diversification and low business segment diversification, about $36 \%$ being classified as low geographic diversification and high business segment diversification, and about $14 \%$ being classified as high geographic diversification and high business segment diversification."

Table 1

Segment Distribution

\begin{tabular}{|l|r|r|r|r|}
\hline & $\mathbf{G}=0 \mathrm{~B}=0$ & $\mathbf{G}=1 \mathrm{~B}=0$ & $\mathrm{G}=0 \mathrm{~B}=1$ & $\mathrm{G}=1 \mathrm{~B}=1$ \\
\hline & & & & \\
\hline Number of observations & 14874 & 3157 & 13077 & 4954 \\
\hline & $41.25 \%$ & $8.75 \%$ & $36.26 \%$ & $13.74 \%$ \\
\hline & & & & \\
\hline No. of geographic segments $\left(^{\star}\right)$ & 1 & $2.36\left(^{\star \star}\right)$ & 1 & $2.48\left({ }^{\star \star}\right)$ \\
\hline No. of business segments $\left({ }^{*}\right)$ & 1 & 1 & $2.98\left({ }^{\star \star}\right)$ & $3.26\left({ }^{\star \star}\right)$ \\
\hline
\end{tabular}

*-pooled mean

**- differences are due to the composition of companies in a given category over the study period

'Sample firms are considered to have low levels of geographic diversification if they report only total domestic operations and total foreign operations as their geographic segments, i.e. one segment. Under SFAS No.14 criteria, firms reporting only domestic operations and total foreign operations as their geographic segments have no one geographic segment exceeding 10 percent of consolidated sales, earnings, or assets. Sample firms are considered to have high levels of geographic diversification if they report two or more geographic segments. Sample firms are considered to have low levels of business segment diversification if they report only one business segment. Sample firms are considered to have high levels of business segment diversification if they report more than one business segment. 
Table 2 shows the mean values of the data items used in the statistical analyses after the screening of data. ${ }^{2}$ The companies in the high business segment diversification category had more missing items than the other groups. Therefore, the composition of companies changed after the screening. Table 2 also shows the variables used in regression analyses where cumulative risk-adjusted equity security returns (i.e., $C A R_{t}$ ) is the dependent variable and earnings changes (i.e., EPS $\left.S_{1}\right)$, capitalized equity value $\left(V_{n}\right)$, price per common share $\left(P_{n}\right)$, and systematic risk of common equity $\left(B_{t}\right)$ are the independent variables. As the regression model is essentially an annual earnings regression the table presents the earnings characteristics of the sample firms.

Table 2

Eamings Characteristics by Categories

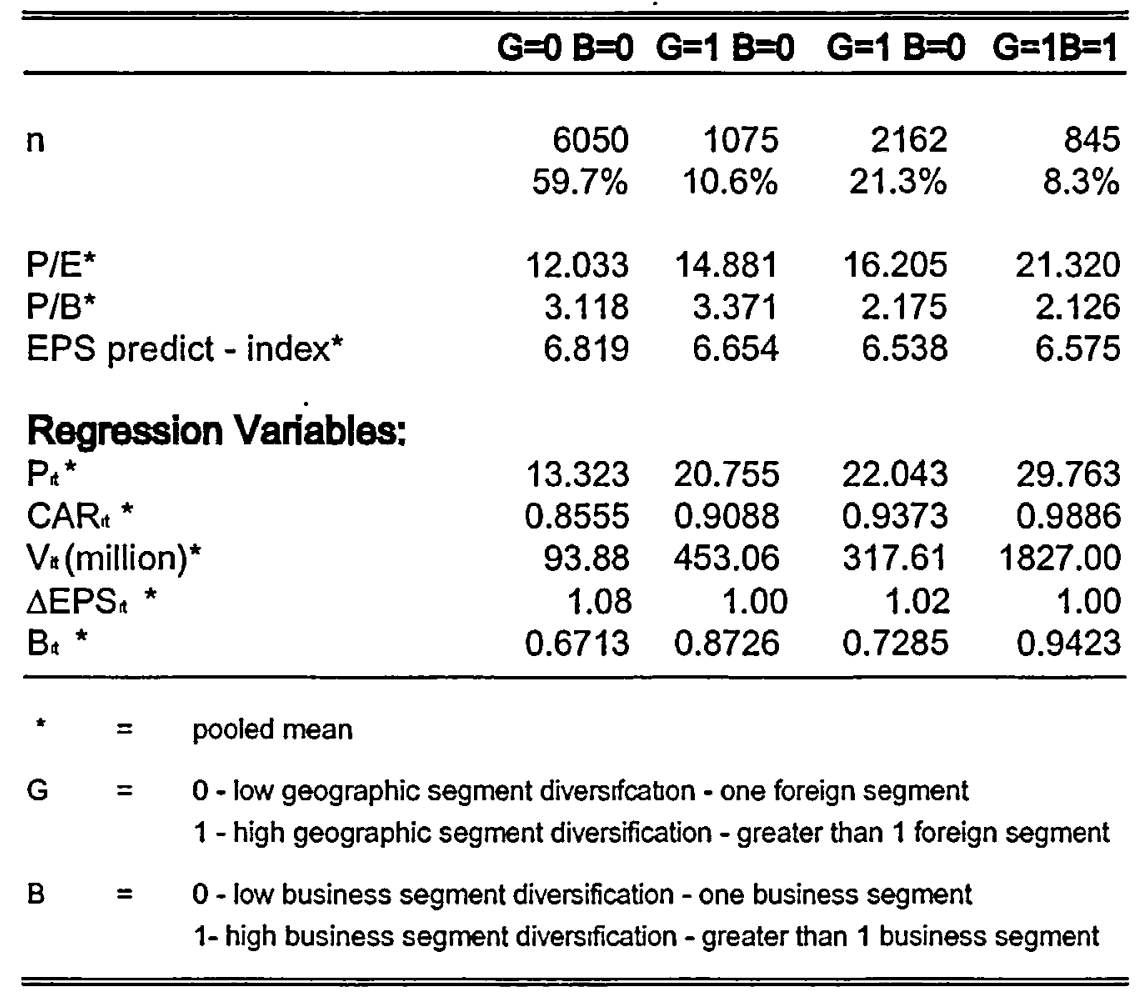

${ }^{2}$ In this study, we utlize firms with no missing data items for the variables descnbed above and do not delete observations considered to be outliers or delete observations for any other reason. All nonmissing firm-observations are used in parameter estimation and statistical tests of hypotheses. We do use approaches to statistical estimation which consider undesirable properties in the distribution of the data. 
In general, firms with greater degrees of both geographic and business segment diversification have smaller annual earnings changes and greater risk-adjusted returns, are larger in terms of capitalized equity value, have larger share prices, and greater systematic risk. The earnings characteristics of such firms show that, on average, they have comparatively more predictable earnings, higher price-toearnings ratios, and lower price-to-book ratios. Consequently, from Table 2 it appears that companies which are diversified both in terms of business and geographic segments provide investors with higher and more stable returns. When we compare high and low geographic segment categories we see that companies with higher segmentation enjoy higher risk adjusted returns, comparatively stable earnings, higher risk and higher prices. A comparison of companies with high and low business segments reveals that business segmentation also has positive impact on the returns.

We utilize cross-sectional pooled earnings response regressions to investigate differential association of magnitudes of annual earnings changes with magnitudes of annual risk-adjusted security returns for U.S.-based MNCs with relatively low and high degrees of geographic and business segment diversification. The specification of the cross-sectional earnings response regression follows Cheng, Hopwood, and McKeown (1992) using rank data transformations and includes as explanatory variables, in addition to earnings variables, price per common share, total capitalized equity value, and systematic risk, in order to improve the specification of the earnings response regression.

$$
\begin{aligned}
C A R_{t}= & \beta_{0}+\beta_{1} \text { Dum }(H L)_{t}+\beta_{2} \operatorname{Dum}(L H)_{t}+\beta_{3} \operatorname{Dum}(H H)_{t}+ \\
& \beta_{4} \Delta E P S(G=L, B=L)_{t}+\beta_{s} \triangle E P S(H L)_{t}+\beta_{6} \Delta E P S(L H)_{t}+ \\
& \beta_{r} \Delta E P S(H H)_{t}+\beta_{s} . P_{t}+\beta_{s} V_{t}+\beta_{t 0} B_{t}+u_{t}
\end{aligned}
$$

\footnotetext{
3 A rank data transformation is used for the independent variables used in Equation (1). The rank transformation substitutes the value of the variable with the value of its sample rank. This technique provides additional confidence in the statistical results because: (1) the results are independent of assumptions regarding the distribution of the data (i.e., it is a distribution free technique); (2) the transformation generalizes the functional form of the regression equation, since it provides the same results as all ordinal transformations; and (3) it mitigates the impact of measurement error, outliers, and residual heteroscedasticity on the regression results. Rank ties are replaced with the mean value, rather than the high or low value. Percentile ranks are used rather than the raw ranks because they are independent of the maximum rank, and, therefore, are more general. Percentile ranks express the variable rank as a percent of the maximum raw rank. Consequently, the data range from zero to one. See Iman and Conover (1979) for detals regarding the use of rank data transformations in regression analysis.
} 


\begin{tabular}{|c|c|}
\hline $\mathrm{CAR}_{t}$ & $\begin{array}{l}\text { is the th firm annual cumulative monthly market adjusted } \\
\text { security return, where } t=0 \text { is the third month following the } \\
\text { year end and } t=-11 \text { is the fourth month following the prior } \\
\text { year end (i.e., } \\
\left.\qquad \text { CARit }=\sum_{t=0} \ln \left(1+R_{t}-R_{m}\right)\right) \text {. }\end{array}$ \\
\hline $\operatorname{Dum}(G B)_{t}$ & $\begin{array}{l}\text { is an incremental intercept dummy variable allowing the inter- } \\
\text { cept term of the regression to vary across the high and low } \\
\text { geographic and business segment diversification partitions of } \\
\text { the sample firms. Dum(LH)it takes a value of one when busi- } \\
\text { ness segment diversity is high and is assigned a value of } \\
\text { zero otherwise. Dum(HH)it takes a value of one when geo- } \\
\text { graphic and business segment diversity are both high and is } \\
\text { assigned a value of zero otherwise. The intercept term b0 } \\
\text { relates to the low geographic segment diversification and low } \\
\text { business segment diversification partition of the sample firms } \\
\text { with. }\end{array}$ \\
\hline$\triangle E P S(G B)$ & $\begin{array}{l}\text { is the th firm change in annual earnings per common share } \\
\text { (i.e., primary earnings per share before discontinued opera- } \\
\text { tions and extraordinary items) for year } t \text { divided by the equity } \\
\text { security share price at the beginning of the fourth month fol- } \\
\text { lowing the preceding year end, } \\
\text { (i.e., } \triangle E P S_{t}=E_{t} \text { - EPS } S_{t-1} \text { ). } \\
\text { Pr-1 } \\
\text { Each geographic and business segment diversification parti- } \\
\text { tioning of the sample firms is assigned an earnings variable } \\
\text { which takes an earnings value if the sample observations } \\
\text { belongs to that geographic and business segment diversifica- } \\
\text { tion partitioning and takes a value of zero otherwise. } \\
\triangle E P S(H H) \text { takes the value of the earnings change variable } \\
\text { when the observation belongs to the high geographic seg- } \\
\text { ment diversification and high business segment diversifica- } \\
\text { tion partition and takes a value of zero otherwise. }\end{array}$ \\
\hline$P_{n}$ & $\begin{array}{l}\text { is the ith firm price per common share at the end of the } \\
\text { third month following the end of year } t \text {. }\end{array}$ \\
\hline$V_{k}$ & $\begin{array}{l}\text { The ith firm total capitalized equity value at the end of } \\
\text { year } t \text { calculated as the product of price per common } \\
\text { share at the end of the third month following year end and } \\
\text { the number of outstanding common shares at year end. }\end{array}$ \\
\hline $\mathrm{B}_{\mathrm{t}}$ & $\begin{array}{l}\text { The ith firm's systematic risk at the end of year } t \text { calculat- } \\
\text { ed as a market model slope coefficient using } 60 \text { months } \\
\text { or returns beginning with the month of year end the pre- } \\
\text { ceding } 59 \text { months. }\end{array}$ \\
\hline$\beta_{0}, \ldots, \beta_{9}$ & $\begin{array}{l}\text { are Ordinary Least-Squares regression parameter esti- } \\
\text { mates, and }\end{array}$ \\
\hline $\mathrm{u}_{\mathrm{t}}$ & $\begin{array}{l}\text { are regression error terms having zero means and con- } \\
\text { stant variance. }\end{array}$ \\
\hline
\end{tabular}

Using the regression specifications shown in the above equation we test the following hypotheses regarding the relative magnitudes of the earnings change coefficients. 
$H_{01}$ : When companies have low-level business segment diversification, the effect of earnings on returns of companies with low and high-level geographic segment diversification will be equal (i.e., : $H_{01}$ : $\beta_{t}=\beta_{5} \mid B=L$ ).

Ho2: When companies have low-level geographic segment diversification, the effect of earnings on returns of companies with low and high-level business segment diversification will be equal (i.e., : $H_{02}: \beta_{4}=\beta_{6} \mid G=L$ )

$\mathrm{H}_{03}$ : When companies have high-level geographic segment diversification, the effect of earnings on returns of companies with low and high-level business segment diversification will be equal (i.e., : $H_{03}$ : $\beta_{5}=\beta_{7} \mid \mathrm{G}=\mathrm{H}$ )

$H_{04}$ : When companies have high-level business segment diversification, the effect of earnings on returns of companies with low and high-level geographic segment diversification will be equal (i.e., : $H_{04}: \beta_{6}=\beta_{7} \mid B=H$ )

These hypotheses will provide additional insight into the impact of geographic and business segment diversification upon the association between annual earnings changes and risk adjusted equity security returns by (1) considering the two types of diversifications individually and separately, and (2) simultaneously controlling the impact of one of the types of diversification while investigating impact of the other on the association between annual earnings changes and risk adjusted equity security returns.

\section{Results and Discussion}

The empirical results for Equation (1) are shown in Table 3 . Table 3 shows the earnings response coefficients for four different models pertaining the hypotheses developed above. The earnings change coefficients are tested to be equal to one another in pairs across the $2 \times 2$ matrix of geographic and business segment strata using two-tailed F-tests.

In general, all of the coefficients have the expected signs and virtually all of the null hypotheses (not specified) that the regression coefficients are individually equal to zero are rejected at the $a=0.05$ confidence level except for the coefficient for capitalized equity value in models one and two, which we attribute to spurious correlation with price per share.

Rejection of the null hypothesis one $\left(\mathrm{H}_{01}: \beta_{4}=\beta_{5} \quad\right.$ I $\left.B=L\right)$ indicates that increased geographic segment diversification increases the association between magnitudes of annual earnings changes and magnitudes of annual risk adjusted equity security returns for firms with low levels of business segment diversification. The coefficient for the earnings change variable for the high-geographic-low-business segment quartile is greater than the earnings change variable for the lowgeographic-low-business segment quartile $\left(3.6 \times 10^{-5}\right.$ and $2.1 \times 10^{-5}$ respectively) signifying the importance of the geographic segment diversification when companies have low business segment diversification. In other words, investors perceive international diversification positively when business segment diversification is low as depicted by the increase in share values. 
Table 3

Results of Regression Analysis Equation (1) and Related Hypotheses Tests Regarding the Magnitude of Coefficients for Earnings Change Variable of Different Geographic Segment and Business Segment Diversification Strata.

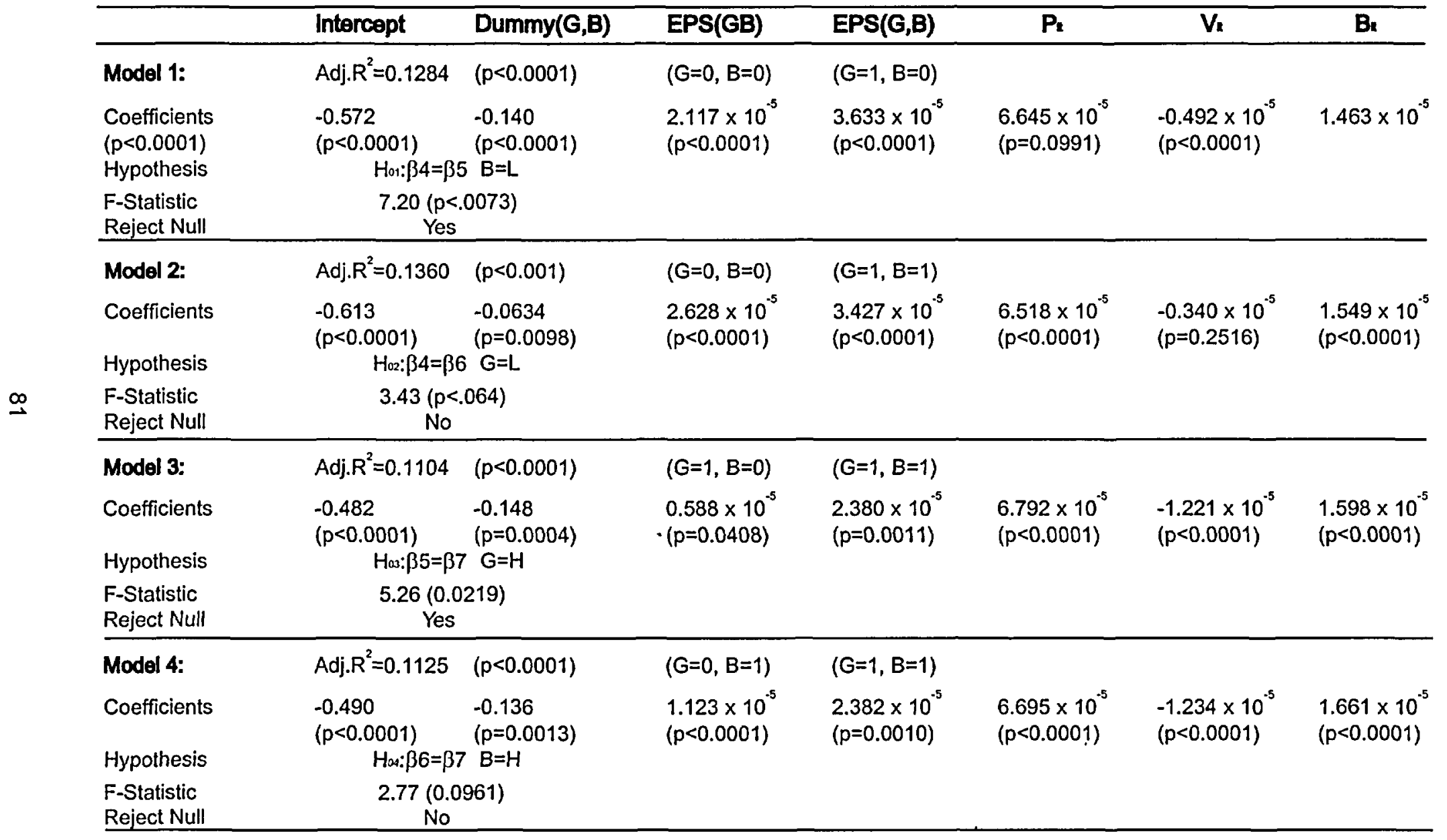

${ }^{*} G$ and $B$ denote levels of geographic and business segment diversification respectively and take values of $L(o w)$ and $H($ igh $)$ depending on the mode 
The second null hypothesis $\left(H_{02}: \beta_{4}=\beta_{6} \mid G=L\right)$ is not rejected at the $a=$ 0.05 confidence level. This result indicates that increasing business segment diversification does not increase the earnings when the firms have low geographic segment diversification. In other words, it appears that the investors do not value business segment diversification in the absence of geographic diversification. One plausible explanation might be that investors believe that firms could better maximize their profits through core competency in domestic markets.

The third null hypothesis ( $\mathrm{H}_{03}: \beta_{5}=\beta_{7} \mid \mathrm{G}=\mathrm{H}$ ) is rejected at the $\mathrm{a}=0.05$ confidence level indicating that earnings changes coefficients for high and low levels of business segment diversification are significantly different from one another when MNCs are well diversified globally. The earnings change coefficient for the high-geographic-high-business segment diversification quartile companies is greater than the earnings change coefficient for the high-geographic-low-business segment diversification companies quartile $\left(2.4 \times 10^{-5}\right.$ and $0.6 \times 10^{-5}$ respectively) showing the influence of earnings on returns in that group of companies.

This finding offers evidence that having high business segment diversification is valued by investors when such firms are also well diversified internationally.

Null hypothesis four $\left(H_{04}: \beta_{6}=\beta_{7} \mid B=H\right)$ is not rejected at the $a=0.05$ confidence level. This result indicates that the regression coefficients of earnings changes for low and high levels of geographic segment diversification are not significantly different from one another when the level of business segment diversification is held constant at the high level. Nevertheless, the earnings change coefficient of companies in the high-geographic segment diversification group is higher than the earnings change coefficient of the low-geographic segment diversification quartile firms. This result suggests that although geographic segment diversification may not carry any additional value beyond that attributable to a high level of business segment diversification for the investors, it still positively contributes to the returns. Investors may perceive geographic segmentation as a vehicle for obtaining higher segment diversification that may lead to higher profitability as reflected in equity share prices of the companies in the high-geographic-high-business segment diversification quartile companies.

The findings of this study support the existing literature that investors incorporate segment information in their decision models. For example, Lobo et al. (1998) show that segment disclosures provide information that improves the forecasting ability of both investors and financial analysts. Likewise, Datta et al. (1991) have shown positive relationship between business diversification and firm performance measures.

Our results show that geographic segment diversification is valued by investors more than the business segment diversification especially in two cases: 1) when the business segmentation is low; and 2) when geographic segmentation is high. The findings of this study suggest that business segment diversification increases the association between magnitudes of annual earnings changes and magnitudes of annual risk adjusted equity security returns only when MNCs also enjoy high geographic segment diversification. This result implies that business segment diversification is only valued when it takes place in international markets where it is relatively more difficult for individual investors to obtain shares of companies from different industries to form a diversified portfolio. 
On the other hand, our results provide a compelling indication that geographic segment diversification increases the association between magnitudes of annual earnings changes and magnitudes of annual risk adjusted equity security returns regardless of the existing level of business segment diversification. Considered together, these results provide a clear picture of the conditional or contextual relation between geographic and business segment diversification and share value. In light of recent developments in segment disclosures, new research is necessary to determine if these findings hold true when management chooses to disclose segments in line with their internal operations.

\section{Conclusion}

In summary, we examine the effect of geographic and business segment diversification upon equity investors' perceptions of U.S.-based multinational corporations' quality of annual earnings changes. Our results provide convincing evidence that U.S.-based multinational corporations with higher geographic segment diversification have greater association between magnitudes of annual earnings changes and equity security returns than U.S.-based multinational corporations with lower geographic segment diversification especially when the companies have low business segmentation diversification. On the other hand, U.S.-based multinational corporations with greater business segment diversification have comparatively similar association between magnitude of annual earnings changes and equity security returns at both high and low levels of geographic segment diversification. In other words, investors may not attribute additional significant value for firms going international when they are operating at high business segment diversification level but they still value the effect of geographic segmentation positively.

Our findings appear consistent with the results of extent literature suggesting that equity securities investors value geographic segment diversification to a greater extent than business segment diversification. This research illuminates the contextual or conditional aspect of investors' perceptions of geographic and business segment diversification by extending inquiry to include multinational corporations annual earnings and simultaneously considering both types of diversification. One particular area that needs to be addressed is the interactive effects of geographic segment and business diversification. 


\section{References}

AIMR, Association for Investment Management and Research, 1993, Financial Reporting in the 1990s and Beyond, Charlottesville, Va:AIMR

AIMR, Association for Investment Management and Research, February 2000, AMR Corporate Disclosure Survey. A Report to AIMR, accessed January 2002, www.aimr.org/pdf/corpdisc.surv.pdf

Arnold, J., W. Holder, and H. Mann, 1980, "International reporting aspects of segment disclosure", International Journal of Accounting Education and Research, $16,125-135$

Balakrishnan, R., T. Harris, and P. Sen, 1990, "The Predictive Ability of Geographic Segment Disclosures", Journal of Accounting Research,18(2), 343-361

Bodnar, G., C. Tang, and J. Weintrop, 1997 "Both sides of corporate diversification: The value impact of geographic and industrial diversification", NBER Working Paper 6224, JEL Nos.F3, G3, International Finance and Microeconomics.

Boatsman, J. R., B.K. Behn, and D.H. Patz, 1993 "A test of the use of geographical segment disclosures", Joumal of Accountina Research (Supplement), 31, 46-64

Brewer, H.,1981, "Investor benefits from corporate international diversification", Journal of Quantitative Analysis, 16, 113-126

Cheng, A., W. Hopwood, and J. McKeown, 1992,"Non-linearity and Specification problems in Unexpected earnings response regression model," The Accounting Review 67(3), 579-598

Coller, M., and B. G. Pierce, 1999, "The New Segment Information:Is it Any Better?", the Journal of Financial Statement Analysis, Winter, 65-72

Datta, D., N. Rajagopalan, and A. Rasheed, 1991"Diversification and performance: Critical review and future directions," Journal of Management Studies, 28, 529-558

Doupnik, T. S., and R .J. Rolfe, 1989, "The relevance of level of aggregation of geographic area data in the assessment of foreign investment risk", In Advances in Accounting, ed. P. M. J. Reckers, 1989, 7, 51-65, Greenwich, CT: JAI Press

Doupnik, T. S, and L. P. Seese, 2001, "Geographic Area Disclosures under SFAS NO.131:materiality and fineness", Journal of International Accounting Auditing and Taxation, 10, 117-138

Errunza, V. and L. Senbet, 1981, "The effects of international operations on market value of the firm: Theory and Evidence", Journal of Finance, 36, 401-417.

Errunza, V. and L. Senbet, 1984, "International corporate diversification, market valuation and size-adjusted evidence", Journal of Finance, 34,727-745. 
Fatemi; A.,1984, "Shareholder benefits from corporate industrial diversification", Journal of Finance, $39,1325-1344$

Financial Accounting Standards Board (FASB), 1976,Financial Reporting for Segments of a Business Enterprise, Statement of Financial Accounting Standards No.14, Stamford, CT: FASB

Financial Accounting Standards Board (FASB) 1997, Disclosures about segments of an enterprise and related information, Statement of Financial Accounting Standards No.131, Stamford, CT: FASB

Gray, S, and L. Radebaugh, 1984, "International Segment Disclosures by U.S. and U.K. Multinational Enterprises: A Descriptive Study", Journal of Accounting Research, 22(1),351-360

Harris, M.S., 1998,"The Association between Competition and Managers' Business Segment Decisions", Journal of Accounting Research, 32(1),111-128

Herrmann, D., and W. B. Thomas, 2000,"An Analysis of Segment Disclosures under SFAS No.131 and SFAS No.14", Accounting Horizons, 14(3),287-302

Hitt, M., R. Hoskisson, and H. Kim,1997, "International Diversification: Effects on Innovation and Firm Performance in Product-Diversified Firms", Academv of Management Journal 40(4), 767-798

Hoskisson, R., Hitt,M., Johnson, R. and Moesel, D. 1993, "Construct validity of an objective (entropy) categorical measure of diversification strategy", Strateqic Management Journal, 14(3): 215-235.

Jones, G., and C. Hill, 1988, "Transaction cost analysis of strategy-structure choice," Strategic Management Journal, 9, 159-172

Kim, W, and E. Lyn, 1986, "Excess market value, the multinational corporation, and Tobin's q ratio", Journal of International Business Studies, 17, 117-126

Lobo, G. J, S. S. Kwon, and G. A. Ndubizu, 1998, "The Impact of SFAS No.14 Segment Information on Price Variability and Earnings Forecast Accuracy", Journal of Business Finance and Accounting, 25(7),969-985

McConnell, P., and P. Pacter, 1995,"IASC and FASB Proposals Would Enhance Segment Reporting", CPA Journal, 65(8), 32-36,50-51

Michel, A., and I. Shaked, 1986, "Multinational corporations vs. domestic corporations: Financial Performance and Characteristics", Journal of International Business Studies, 18, 89-100

Mikhail, A., and H. Shawky, 1979,"Investment performance of U.S.-based multinational corporations", Journal of International Business Studies, 10, 53-66 
Morck, R., and B. Yeung, 1991, "Why investors value multi nationality?", Journal of Business, 64, 165-187

Nichols, N.B., D. L. Street, and S. J. Gray, 2000, "Geographic Segment Disclosures in the United States: Reporting Practices Enter A New Era", Journal of International Accounting. Auditing and Taxation.9(1).59-82

Palepu, K., 1985,"Diversification strategy, profit performance and the entropy measure," Strateqic Management Joumal, 6,239-255

Prahalad, C. and G. Hamel, 1990,"The core competence of the corporation," Harvard Business Review 68(3),79-91

Prather-Stewart, J., 1995, "The information content of geographic segment disclosures", Advances in International Accounting, ed. T.S. Doupnik, 31-45, Greenwich, CT, JAI Press Inc

Street, D., N.B. Nichols, and S.J. Gray, 2000, "Segment Disclosures under SFAS No.131:Has Business Segment Reporting Improved?", Accounting Horizons,259285

Tallman, S., and J. Li, 1996, "Effects of International Diversity and Product Diversity on the Performance of Multinational Firms", Academv of Management Joumal, 39(1), 179-196

Teece, D., G. Pisano, and A. Shuen, 1990, "Firm capabilities, resources, and the concept of strategy: four paradigms of strategic management," CCC working paper, University of California, Berkeley, 90-98

Thomas, W.B., 2000, "The Value-relevance of Geographic Segment Earnings Disclosure Under SFAS 14", Journal of International Financial Management and Accounting, 11(3), 133-155 